At the opening ceremony of the exhibition in the Clementinum, the delegates enjoyed a performance to ancient Bohemian polyphonous music sung by the Bohemian madrigalists conducted by Prof. B. Špidra. This improvised concert deeply impressed the visitors, as also did the compositions of Rejcha and Mozart played in the large hall of the Wallen. stein Palace by the Prague brass quintette. The performance of Weber's "Oberon" in the Prague German Theatre, and that of Smetana's "Libuše" in the National Theatre, as well as the concert of the Czech Philharmonic Orchestra at the Smetana Hall conducted by Mr. Rafael Kubelik, offered further opportunities for the delegates to become acquainted with the cultural life of Czechoslovakia.

Among the resolutions submitted and approved at the final meeting of the Congress was a proposal that history of science should be included in the teaching of secondary and high schools, and also a request for the publication of Isaac Newton's correspondence.

An invitation from the Swiss Government to hold the next congress at Lausanne in 1940 was accepted, and Prof. Arnold Raymond, formerly rector of the University of Lausanne, was elected president. An invitation from the Brazilian Government to an extraordinary congress in 1938 was also accepted.

\title{
Overvoltage in Light and Heavy Water
}

$\mathrm{B}^{\mathrm{x}}$ means of the polarographic method with a dropping mercury cathode, Prof. J. Heyrovský, in collaboration with Dr. J. Novák, has been able to advance knowledge of hydrogen overvoltage (Coll. Czechoslovak Chem. Com., 9, 207, 273 and 344; 1937). By this delicate method they were able to register significant differences in current voltage curves in light and heavy water, with special reference tc hydrogen overvoltage. They find that in $0.001 \mathrm{~N}$ hydrochloric acid in ordinary water at $20^{\circ} \mathrm{C}$. the overvoltage differs from that in $99 \cdot 6$ per cent deuterium oxide by +87 millivolts; in 94.6 per cent $\mathrm{D}_{2} \mathrm{O}$ by 63 millivolts; in 76.5 per cent $\mathrm{D}_{2} \mathrm{O}$ by $31 \mathrm{mv}$. and in 49.8 per cent $\mathrm{D}_{2} \mathrm{O}$ by $15 \mathrm{mv}$. At $60^{\circ} \mathrm{C}$. the differences with the purest heavy water is +71 millivolts. The factor $b$ in Tafel's term, $b \log i$, is 113 millivolts at $20^{\circ} \mathrm{C}$. in heavy water and 102 in light water.

The electro-reduction of hydrogen peroxide is similarly inhibited in heavy water. On the other hand, the electro-reduction of oxygen, and of maleic acid in acetic acid solution, and the electro-deposition of thallous ions in heavy water proceed at an unchanged potential or at a distinctly more positive one than in light water. The theoretical significance of these experimental results is discussed by Prof. Heyrovský, who gives a general theory of hydrogen overvoltage which appears to account well for the observed facts. $\mathrm{He}$ regards the electro-deposition of the isotopic hydrions as indifferent, but the evolution of hydrogen, including its molalization, as 5.4 times less in heavy water ; 5.4 is the ratio of the ionic products of $\mathrm{H}_{2} \mathrm{O}$ and $\mathrm{D}_{2} \mathrm{O}$, and signifies that the rate of dissociation of water is $5 \cdot 4$ times that of deuterium oxide. The molalization takes place through the interaction of the deposited hydrogen atoms with the hydrions of the solution:

$$
\mathrm{H}+\mathrm{H}^{+}=\mathrm{H}_{2}+
$$

The formula finally deduced for the overvoltage is

$$
\begin{array}{r}
\pi=+\frac{R T}{F} \log \frac{([\mathrm{H}+]+[\mathrm{D}+])^{2}}{i+\bar{\omega} i^{2}}\left(C_{\mathrm{H}_{2} \mathrm{O}} K_{1}+C_{\mathrm{HOD}}\right. \\
\left.\left(K_{1}^{\prime}+K_{2}{ }^{\prime}\right)+C_{\mathrm{D}_{2} \mathrm{O}} K_{2}\right),
\end{array}
$$

where $\tilde{\omega}$ is the mean adsorption coefficient of the freshly formed hydrogen molecules, $\mathrm{CH}_{2} \mathrm{O}, C \mathrm{HOD}$ and $\mathrm{CD}_{2} \mathrm{O}$ denote the molar fractions of the solvent, and $K_{1}\left(K_{1}^{\prime}+K_{2}^{\prime}\right)$ and $K_{2}$ are the dissociation constants of $\mathrm{H}_{2} \mathrm{O}$, HOD and $\mathrm{D}_{2} \mathrm{O}$ respectively.

The validity of the equation has been tested by substituting calculated quantities of light and heavy water, and the observed results are in good agreement with theoretical requirements. The electrolytic separation coefficient for the hydrogen isotopes at cathodes with large overvoltage is dependent on the composition of the mixture and on the current density. The mean value of $5 \cdot 4$ should increase to 50 in concentrated heavy water and decrease to $2 \cdot 7$ in ordinary water.

\section{Employment of University Graduates}

Y FidR by year some 15,000 students enter the universities of Great Britain. Their intentions, hopes and aspirations and those of their parents and other counsellors are almost as various as their pedigrees, but they are admitted on the assumption that their undergraduate years are to be dedicated more or less to preparation for their life's work, and the shaping of university policies is to a large extent determined by that ideal. In their careers after the completion of their undergraduate courses, the value of that preparation is tested, and the employment of graduates is, obviously, a matter of concern not only to them but also to university administrators and to the community as a whole.

The University Grants Committee in its quinquennial report published last year dealt at consider. able length with problems of student numbers and employment. This year the National Union of Students held a Congress at Southampton on April I-8, at which these formed the main subject of 
discussion, the actual title given to the Congress being "Training for What ?" The subject was chosen after a serious and sustained effort on the part of the National Union (in association with local unions) to elucidate some of these problems-an effort frustrated to some extent by want of statistics.

For the university statistician, a student ceases to exist from the moment when he ceases to be an active member of the university, and in the absence of authentic statistical data, only conjectural, vague or partial answers can be obtained to such questions as: How many graduates, with what qualifications, were seeking employment twelve months after leaving the university? How many specially prepared for certain vocations have accepted employment in other fields?

This matter of the lack of official statistics of employment of graduates was repeatedly mentioned in the University Grants Committee's report, but without any indieation that the Committee thought anybody ought to do anything about it. The Congress report stresses the importance of a comprehensive knowledge of the actual facts about graduate employment, and takes the view that it is 'up to' the universities to acquaint themselves with the practical results of their methods of undergraduate education. Foremost among the topics dealt with by one of the three sections of the Congress, the Commerce and Industry section, was "the work and functions of a university appointments board", the pressing importance of which had been emphasized last year by the University Grants Committee. The results of the discussion of this topic were formulated as a series of definite recommendations, now published in an appendix to the report, including one to the effect that every university appointments board should be charged with the duty of obtaining information about the employment (including unemployment and misemployment) of graduates, and tabulating it in standardized forms.

It is worth noting that in the case of the University of Wales, the matter is somewhat simplified by the fact that every graduate is, by virtue of graduation, a member of the Guild of Graduates of the University. A valuable report by the secretary of the Guild on "Graduate Unemployment in Wales", published as Appendix D to the Congress report, shows that the Guild's standing committee is a resourceful and influential body. The report is based mainly on replies to 2,250 questionnaires distributed last November. The fact that only 60 per cent were answered suggests that something more compelling than membership of a guild is needed.

So much for statistics. The Congress discussions ranged over many other important matters, among them being the prospects of increased employment of graduates in primary schools and in the local government services.

As pointed out in an article in The Times Educational Supplement of September 4 on "Openings for Graduates", the primary schools present a field of service second to none in national importance. The rapid expansion of staff requirements for secondary schools since 1902 has had a most unfortunate result as regards the staffing of the elementary schools. The idea of attracting recruits for these schools from among university graduates was allowed to lapse and a cleavage of type between the teachers in the elementary and those in the secondary and 'public' schools became firmly established. The graduates who now find their way into elementary schools do so, in general, with reluctance, having failed to obtain employment in secondary schools (for which their training was designed to fit them) and are liable to be regarded with disfavour by their co-workers on that account. Some approach towards unification of conditions of service in the elementary and secondary schools suggests itself as a promising first step towards remedying this unfortunate state of affairs, and one of the Congress resolutions proposed that the Onslow Committee in its investigations into salary scales should be urged to remedy the more glaring inequalities.

The situation is aggravated by the fact that many of the students in the teacher-training departments not merely dislike the idea of teaching in elementary schools but do not really wish to teach at all. "Many of them," says the report, "had obtained a Board of Education grant because it was the only way by which they could obtain the benefits of a university education, while others had drifted into teaching through the absence of any apparent alternative". While lamenting this result of the Board's system of grants, affecting both elementary and secondary schools, it is well to remember that dissatisfaction with one's work is a complaint by no means peculiar to the teaching profession-or to the present age (Horace satirized it). The Education section of the Congress suggested as a remedy "the institution of a greatly increased number of scholarships or grants which, while they would still cater for the needs of the poor student, would not bind the holder in advance to the pursuit of any particular career".

As regards the recruitment of graduates for the local government services, it is perfectly clear that local authorities are proof against persuasion in the form of impressively worded recommendations supported by apparently flawless arguments such as are to be found in the final report of the Royal Commission on Local Government, the report of the Hadow Departmental Committee on Qualifications, Recruitment, Training and Promotion of Local Government Officers, and the reports of the University Grants Committee. Mr. Chuter Ede, chairman of the Surrey County Council, addressed the Professions and Public Services section of the Congress on this subject. He suggested one-year post-graduate courses in the principles and practices of local government, and that the universities should agitate for the institution of competitive examination for appoint. ments to local government service. Discussion of these and other suggestions led to the adoption of resolutions that the N.U.S. should consider co-operation with professional associations such as the National Association of Local Government Officers and that university authorities should be approached in the matter of courses of training for the public services including courses open to persons already in local government service. It had transpired in the course of discussion that in London and Liverpool time is allowed to local government employees for attendance on university courses, and it was thought that in the general adoption of such an arrangement was to be found a hopeful line of approach to the desired liaison between universities and local authorities in relation to appointments. Sir Richard Livingstone's plea, in his address on September 6 to Section $\mathbf{L}$ of the British Association, for adult education of a new type, should help to speed sucb a movement.

The ever-growing complexity of the modern world is continually throwing up new opportunities for the 
employment of trained intelligence. The report takes the view that university students are too prone to ignore all avenues to worthwhile occupations other than the beaten paths of teaching, medicine, engineering, law, civil service, the church and set courses in industry and commerce. "Arts graduates, especially, rarely think of any possible occupation other than teaching". Such considerations point to the need for more recourse to vocational guidance. A firstyear course on careers, available for all students, was advocated in an address by Prof. J. H. Jones of the University of Leeds. It should aim at "the development of some conception of citizenship and social responsibility" and should be given, not by an appointments officer but by a number of persons experienced in their profession and in the life and purpose of a university. It should be voluntary, but time should be allowed from existing first-year courses to enable students in all faculties to attend. The Congress recorded its approval of the introduction of such orientation courses coupled with a recommendation of vocational guidance by 'careers masters' in schools and appointments boards in universities, mutually co-operating.
The question of limitation of entry into universities has an obvious bearing on graduate employment. This prickly subject is touched on in the report somewhat gingerly. Fairly general agreement was reached in discussions in the Commerce and Industry section that universities ought to select from among can. didates for admission only those capable of a dis. tinctively university type of education, "an education in which the student is not so much taught as provided with the tools for the acquisition of knowledge and technique", others being referred to suitable institutions providing higher education of a technical character. Presumably such a selection would be made after a brief probationary period of membership in the university. The report recognizes that any recommendation from a student body that there should be any limitation of educational opportunities might be open to misconstruction and abuse, and suggests, therefore, that the whole matter should be inquired into further by a thoroughly competent commission. The matter is certainly one of enormous importance, but it is difficult to imagine the desired reform being effected without infringing the autonomy of the universities.

\section{Engineering Progress in the Navy}

$\mathrm{I}^{\mathrm{N}}$ taking office, for a second term, as president of the North-East Coast Institution of Engineers and Shipbuilders, Prof. C. J. Hawkes delivered an address in which he reviewed some recent history of the engineering branch of the Royal Navy, established by Orders in Council just a hundred years ago. He referred in particular to the period of his own service, dating from 1900 , when great difficulties were being encountered with large water-tube boilers of the Belleville type. Smalltube Thornycroft boilers had given good results in H.M.S. Speedy in 1893. The decision in 1894 to install Belleville boilers in the 25,000 h.p. cruisers Powerful and Terrible was a momentous one and raised a storm of protest. The trials were satisfactory and demonstrated the weight-saving advantages, but later performance was disappointing, breakdowns were frequent and leakage was excessive, thus giving point and momentum to the attacks in Parliament and Press. The committee set up to investigate, however, confirmed the advantages and greater suitability of the water-tube as compared with the cylindrical boiler for use in the Navy. Improved methods of construction and the installation of special machinery in the dockyard enabled the Belleville boilers to give good service, but owing to inherent defects, including the long water and steam course of about $170 \mathrm{ft}$., some irregularity in water circulation and the deformation of tubes by local heating, it ultimately gave place to more modern designs.

In 1904, oil fuel as a supplement to coal was sanctioned, and seven years later it was decided that all new cruisers and battleships should be designed to burn oil only. Although this was a change of great national importance, it aroused none of the violent passions associated with the introduction of the large-tube water-tube boiler. From the engineer- ing point of view and that of the ship as a fighting unit, oil firing has several important advantages over hand-fired coal for steam raising. As native sources of supply are as yet quite inadequate to meet the needs of the Navy even in time of peace, the position is a difficult one, but so necessary is it that the Admiralty has decided to continue its use for steam raising in the Fleet. The production of oil fuel from coal is therefore being encouraged.

Up to 1900 all warships were propelled by reciprocating steam engines; the T.B.D. Viper was the first to have turbines. There were early difficulties in operating turbines at cruising speed and at full speed, but these were so far overcome that in 1905 it was decided that all future warships be fitted with turbine machinery and, in that year, the Dreadnought, the first turbine-driven battleship, was laid down. At first turbines were direct-coupled to propeller shafts, but from 1911 gearing was used, resulting in increased propulsive efficiency and reduced fuel consumption per shaft horse-power. The lubrication of multiple-thrust blocks was a constant difficulty and the author quotes a case in which, at a certain speed, the flow was reversed and oil from the thrust-block wells overflowed from the oil boxes situated 10-12 feet above the shaft. A system of forced lubrication was thereupon devised and worked without trouble, but the real solution came with the invention of the Michell thrust-block, which alone has made present-day shaft loads practicable.

Prof. Hawkes gave figures to show the saving of weight and space which has resulted from these and other improvements, the more marked as they are accompanied by greater reliability and durability. Further advances may be looked for, but it must be borne in mind that in naval design there are limita. tions which do not apply to land practice. 